\title{
Physical Mapping of the 5S and $18 S$ rDNA in Ten Species of Hypostomus Lacépède 1803 (Siluriformes: Loricariidae): Evolutionary Tendencies in the Genus
}

\author{
Vanessa Bueno, ${ }^{1}$ Paulo César Venere, ${ }^{2}$ Jocicléia Thums Konerat, ${ }^{3}$ \\ Cláudio Henrique Zawadzki, ${ }^{4}$ Marcelo Ricardo Vicari, ${ }^{5}$ and Vladimir Pavan Margarido ${ }^{3}$ \\ ${ }^{1}$ Universidade Tecnológica Federal do Paraná, Prolongamento da Rua Cerejeira s/n, São Luiz, 85892-00l Santa Helena, PR, Brazil \\ ${ }^{2}$ Departamento de Biologia e Zoologia, Universidade Federal de Mato Grosso, Instituto de Biociências, \\ Avenida Fernando Correa da Costa s/n, Coxipó, 78060-900 Cuiabá, MT, Brazil \\ ${ }^{3}$ Universidade Estadual do Oeste do Paraná, Centro de Ciências Biológicas e da Saúde, Rua Universitária 2069, \\ 85801-110 Cascavel, PR, Brazil \\ ${ }^{4}$ Departamento de Biologia/Nupélia, Universidade Estadual de Maringá, Avenida Colombo 5790, 87020-900 Maringá, PR, Brazil \\ ${ }^{5}$ Departamento de Biologia Estrutural, Molecular e Genética, Universidade Estadual de Ponta Grossa, \\ Avenida Carlos Cavalcanti 4748, 84030-900 Ponta Grossa, PR, Brazil
}

Correspondence should be addressed to Vladimir Pavan Margarido; vladimir.margarido@unioeste.br

Received 30 July 2014; Accepted 24 September 2014; Published 27 October 2014

Academic Editor: Adayabalam S. Balajee

Copyright (c) 2014 Vanessa Bueno et al. This is an open access article distributed under the Creative Commons Attribution License, which permits unrestricted use, distribution, and reproduction in any medium, provided the original work is properly cited.

\begin{abstract}
Hypostomus is a diverse group with unclear aspects regarding its biology, including the mechanisms that led to chromosome diversification within the group. Fluorescence in situ hybridization (FISH) with 5S and 18S rDNA probes was performed on ten Hypostomini species. Hypostomus faveolus, $H$. cochliodon, $H$. albopunctatus, $H$. aff. paulinus, and $H$. topavae had only one chromosome pair with $18 \mathrm{~S}$ rDNA sites, while H. ancistroides, H. commersoni, H. hermanni, H. regani, and H. strigaticeps had multiple $18 \mathrm{~S}$ rDNA sites. Regarding the $5 \mathrm{~S}$ rDNA genes, $H$. ancistroides, H. regani, $H$. albopunctatus, $H$. aff. paulinus, and $H$. topavae had $5 \mathrm{~S}$ rDNA sites on only one chromosome pair and $H$. faveolus, $H$. cochliodon, $H$. commersoni, $H$. hermanni, and $H$. strigaticeps had multiple $5 \mathrm{~S}$ rDNA sites. Most species had $18 \mathrm{~S}$ rDNA sites in the telomeric region of the chromosomes. All species but $H$. cochliodon had 5S rDNA in the centromeric/pericentromeric region of one metacentric pair. Obtained results are discussed based on existent phylogenies for the genus, with comments on possible dispersion mechanisms to justify the variability of the rDNA sites in Hypostomus.
\end{abstract}

\section{Introduction}

Loricariidae is a species-rich and diverse family, distributed through Central and South America [1, 2]. It is composed of seven subfamilies: Delturinae, Hypoptomatinae, Hypostominae, Lithogeneinae, Loricariinae, Neoplecostominae, and Otothyrinae [1, 3-5]. The Hypostominae contain a great number of nominal species with unclear status, and the systematics of the subfamily is not well resolved [3]. Armbruster [1] proposed the division of the subfamily in five tribes, namely, Corymbophanini, Rhinelepini, Hypostomini, Pterygoplichthini, and Ancistrini. The only genus recognized for Hypostomini would be Hypostomus, with Aphanotorulus, Cochliodon, Isorineloricaria, Squaliforma, and Watwata as synonyms. However, molecular studies based on mitochondrial rRNA gene sequences, $D$-loop, and ITS sequences indicated relevant distinctions among Squaliforma, Isorineloricaria, Aphanotorulus, and Hypostomus, therefore not supporting the synonymization of these genera with Hypostomus $[6,7]$. Further analyses have not been performed on the Hypostomini to verify which genera should be recognized, and there seems to be no consensus about which phylogeny should be adopted for Hypostomus, with a number of further 
studies about other aspects of the genera considering each hypothesis as valid.

Karyotypic studies of Hypostomus initiated with the analysis of Hypostomus plecostomus (Linnaeus 1758) [8]. The diploid number found, $2 n=54$ chromosomes, is the lower diploid number observed for the genus. Further studies showed diploid numbers ranging from $2 n=64$ to $2 n=84$ chromosomes $[9,10]$, indicating that the specimens analyzed by Muramoto et al. [8] might have been misidentified [9]. The number of species cytogenetically analyzed is increasing, but is still far from representing a significant portion of the genus [11]. Also, most studies discuss only the diploid number and location of the AgNORs, ignoring important markers as heterochromatin distribution and mapping of rDNAs sites.

Few species of Hypostomus had their rDNA sites mapped. The lack of information on the number and location of the $5 \mathrm{~S}$ and $18 \mathrm{~S}$ rDNA sites in Hypostomus hinders a broad comparative analysis for the genus. Since the relationships among species of Hypostomus are still unclear, the present study aims to perform the mapping of $5 \mathrm{~S}$ and $18 \mathrm{~S}$ rDNA of ten species of Hypostomus comparing the results with available data for this group to verify the existence of possible evolutionary trends on the genus regarding this trait.

\section{Material and Methods}

The specimens were captured from three distinct Brazilian localities: Piquiri River (municipality of Nova Laranjeiras, Paraná state, Upper Paraná River basin), Iguaçu River (municipality of Foz do Iguaçu, Paraná state, Middle Paraná River basin), and Taquaralzinho River (municipality of Barra do Garças, Mato Grosso state, Upper Araguaia River basins). The collection sites, number of males and females, and catalog numbers of voucher specimens, which were deposited in the Coleção Ictiológica do Núcleo de Pesquisas em Limnologia, Ictiologia e Aquicultura-Nupélia-Universidade Estadual de Maringá, Brazil, are summarized in Table 1. The specimens were anesthetized and sacrificed through clove-oil overdoses [13]. Metaphasic cells were obtained from the kidney through the air-drying technique [14]. Fluorescence in situ hybridization was performed according to Pinkel et al. [15], with modifications suggested by Margarido and MoreiraFilho [16]. The 18S rDNA probes were obtained according to Hatanaka and Galetti [17], and 5S rDNA probes were obtained according to Martins and Galetti Jr. [18]. The probes were marked through nick translation, with biotin-16-dUTP (18S rDNA) and digoxigenin-11-dUTP (5S rDNA) (Roche). Detection and amplification of the hybridization signals were performed with avidin-FITC and antiavidin biotin (SigmaAldrich) for the $18 \mathrm{~S}$ rDNA probes, and antidigoxigenin rhodamine (Roche Applied Science) for the 5S rDNA probes. The slides were counterstained with DAPI and analyzed on the epifluorescence microscope Olympus BX 61. Thirty metaphases per individual were analyzed. Chromosomes were classified according to Levan et al. [19].

\section{Results}

Hypostomus faveolus Zawadzki, Birindelli, and Lima, 2008, H. cochliodon Kner, 1854, H. albopunctatus (Regan, 1908), $H$. aff. paulinus (Ihering, 1905), and H. topavae (Godoy, 1969) had only one chromosome pair with $18 \mathrm{~S}$ rDNA sites, while H. ancistroides (Ihering, 1911), H. commersoni Valenciennes, 1836, H. hermanni (Ihering, 1905), H. regani (Ihering, 1905), and $H$. strigaticeps (Regan, 1908) had multiple 18S rDNA sites. All species had $18 \mathrm{~S}$ rDNA sites located in the telomeric region of the chromosomes. As for the $5 \mathrm{~S}$ rDNA, $H$. ancistroides, $H$. regani, $H$. albopunctatus, $H$. aff. paulinus, and $H$. topavae had $5 \mathrm{~S}$ rDNA sites on only one chromosome pair, and $H$. faveolus, $H$. cochliodon, $H$. commersoni, $H$. hermanni, and H. strigaticeps had multiple $5 \mathrm{~S}$ rDNA sites (Figures 1,2, and 3 ). The number and position of both $5 \mathrm{~S}$ and $18 \mathrm{~S}$ rDNA differed between the populations for $H$. commersoni, and both populations showed syntenic sites. The chromosome size difference in H. commersoni (pair 31) is due to a heterochromatic block that is amplified in just one homologous of the chromosome pair. Results are summarized in Table 2, along with the available data for localization of rDNA in Hypostomus.

\section{Discussion}

A single pair bearing 5S and 18S rDNA sites has been considered plesiomorphic for Loricariidae, given that this characteristic was observed in the outgroup Trichomycteridae and some other Loricariidae genera (Neoplecostomus, Kronichthys, Isbrueckerichthys, and Parotocinclus) considered phylogenetically basal through morphological analysis [1, 27]. Artoni and Bertollo [28] also consider single NORs as the ancestral phenotype for Loricariidae. These characteristics observed on basal genera for Loricariidae, besides other tribes of Hypostominae such as Pterygoplichthini and Ancistrini $[23,29]$, support the hypothesis that the presence of one site of $5 \mathrm{~S}$ and $18 \mathrm{~S}$ rDNAs is basal for Hypostomus.

It is known that the diploid numbers of Hypostomus are likely correlated with their phylogeny and distribution [9]. The following discussion relies on this correlation and on existent phylogenies for the genus; therefore, the discussion will be organized according to diploid number ranges. The correlation among diploid numbers, data obtained from the present paper, and phylogenetic relationships of Hypostomus are simplified in Figure 4. Hypostomus faveolus and $H$. cochliodon are the species with the lower diploid numbers in Hypostomus that had the $5 \mathrm{~S}$ and $18 \mathrm{~S}$ rDNA location mapped. Both species had a single pair bearing $18 \mathrm{~S}$ rDNA, although on different positions on the chromosome for each species, and multiple chromosomes bearing 5S rDNA. Considering the diploid number of 54 chromosomes basal for the family Loricariidae, lower diploid numbers would be considered basal for Hypostomus [30]. Also, a phylogenetic analysis performed by Martinez [12] with the sequences of mitochondrial cytochrome $b$ and partial sequences of the $16 \mathrm{~S}$ rRNA and nuclear F-reticulon 4 genes considered $H$. faveolus the most basal species for Hypostomus. The status of $H$. faveolus as a basal species is compatible with our results, since 
TABLE 1: Species, collection sites, and number of analyzed specimens and catalog numbers (NUP) of the specimens deposited in the ichthyological collection of the Núcleo de Pesquisas em Limnologia, Ictiologia e Aquicultura.

\begin{tabular}{|c|c|c|c|c|}
\hline Species & Males & Females & Locality & NUP \\
\hline Hypostomus albopunctatus & 3 & 3 & $\begin{array}{l}\text { Piquiri River, Nova Laranjeiras } \\
24^{\circ} 56^{\prime} 54^{\prime \prime} \mathrm{S} ; 52^{\circ} 35^{\prime} 49^{\prime \prime} \mathrm{W}\end{array}$ & 13532 \\
\hline Hypostomus ancistroides & 4 & 11 & $\begin{array}{l}\text { Piquiri River, Nova Laranjeiras } \\
24^{\circ} 56^{\prime} 54^{\prime \prime} \mathrm{S} ; 52^{\circ} 35^{\prime} 49^{\prime \prime} \mathrm{W}\end{array}$ & 3902 \\
\hline Hypostomus cochliodon & 4 & 1 & $\begin{array}{l}\text { Iguaçu River, Foz do Iguaçu } \\
25^{\circ} 38^{\prime} 53^{\prime \prime} \mathrm{S} ; 54^{\circ} 27^{\prime} 28^{\prime \prime} \mathrm{W}\end{array}$ & 13541 \\
\hline \multirow[t]{2}{*}{ Hypostomus commersoni } & 0 & 1 & $\begin{array}{l}\text { Piquiri River, Nova Laranjeiras } \\
24^{\circ} 56^{\prime} 54^{\prime \prime} \mathrm{S} ; 52^{\circ} 35^{\prime} 49^{\prime \prime} \mathrm{W}\end{array}$ & \multirow{2}{*}{13540} \\
\hline & 1 & 1 & $\begin{array}{l}\text { Iguaçu River, Foz do Iguaçu } \\
25^{\circ} 38^{\prime} 53^{\prime \prime} \mathrm{S} ; 54^{\circ} 27^{\prime} 28^{\prime \prime} \mathrm{W}\end{array}$ & \\
\hline Hypostomus faveolus & 7 & 2 & $\begin{array}{l}\text { Taquaralzinho River, Barra do Garças } \\
15^{\circ} 40^{\prime} 42^{\prime \prime} \mathrm{S} ; 52^{\circ} 17^{\prime} 52^{\prime \prime} \mathrm{W}\end{array}$ & 13539 \\
\hline Hypostomus hermanni & 5 & 4 & $\begin{array}{l}\text { Piquiri River, Nova Laranjeiras } \\
24^{\circ} 56^{\prime} 54^{\prime \prime} \mathrm{S} ; 52^{\circ} 35^{\prime} 49^{\prime \prime} \mathrm{W}\end{array}$ & 4927 \\
\hline Hypostomus regani & 5 & 6 & $\begin{array}{l}\text { Piquiri River, Nova Laranjeiras } \\
24^{\circ} 56^{\prime} 54^{\prime \prime} \mathrm{S} ; 52^{\circ} 35^{\prime} 49^{\prime \prime} \mathrm{W}\end{array}$ & 13534 \\
\hline Hypostomus aff. paulinus & 6 & 7 & $\begin{array}{l}\text { Piquiri River, Nova Laranjeiras } \\
24^{\circ} 56^{\prime} 54^{\prime \prime} \mathrm{S} ; 52^{\circ} 35^{\prime} 49^{\prime \prime} \mathrm{W}\end{array}$ & 13535 \\
\hline Hypostomus strigaticeps & 8 & 7 & $\begin{array}{l}\text { Piquiri River, Nova Laranjeiras } \\
24^{\circ} 56^{\prime} 54^{\prime \prime} \mathrm{S} ; 52^{\circ} 35^{\prime} 49^{\prime \prime} \mathrm{W}\end{array}$ & 13536 \\
\hline Hypostomus topavae & 9 & 6 & $\begin{array}{l}\text { Piquiri River, Nova Laranjeiras } \\
24^{\circ} 56^{\prime} 54^{\prime \prime} \mathrm{S} ; 52^{\circ} 35^{\prime} 49^{\prime \prime} \mathrm{W}\end{array}$ & 11430 \\
\hline
\end{tabular}

TABLE 2: Available data regarding 5S/18S rDNA distribution in Hypostomus.

\begin{tabular}{|c|c|c|c|c|c|c|}
\hline Species & $2 n$ & Karyotypic formula & $5 \mathrm{~S}$ & $18 \mathrm{~S}$ & Locality & Reference \\
\hline H. cochliodon & 64 & $12 m+16 s m+16 s t+20 a$ & Multiple & Simple & Paraná River basin & Present paper \\
\hline H. faveolus & 64 & $18 m+8 s m+22 s t+16 a$ & Multiple & Simple & Araguaia River basin & Present paper \\
\hline H. affinis & 66 & $14 m+14 s m+12 s t+26 a$ & Multiple & Multiple & Paraíba do Sul River basin & {$[20,21]$} \\
\hline H. tapijara & 66 & $14 m+24 s m+14 s t+14 a$ & Multiple & Multiple & Ribeira do Iguape basin & {$[22]$} \\
\hline H. prope plecostomus & 68 & $12 m+16 s m+12 s t+28 a$ & - & Simple & Orinoco River basin & {$[23]$} \\
\hline H. ancistroides & 68 & $10 m+26 s m+32 a$ & - & Multiple & Paranapanema River basin & {$[24]$} \\
\hline H. ancistroides & 68 & $14 m+14 s m+8 s t+32 a$ & Simple & Multiple & Paraná River basin & Present paper \\
\hline H. ancistroides & 68 & $14 m+16 s m+22 s t+16 a$ & Multiple & Multiple & Paranapanema River basin & {$[22]$} \\
\hline H. commersoni & 68 & $12 m+14 s m+14 s t+28 a$ & Multiple & Multiple & Paraná River basin (Iguaçu River) & Present paper \\
\hline H. commersoni & 68 & $12 m+14 s m+14 s t+28 a$ & Multiple & Multiple & Paraná River basin (Piquiri River) & Present paper \\
\hline H. hermanni & 72 & $10 m+8 s m+32 s t+22 a$ & Multiple & Multiple & Paraná River basin & Present paper \\
\hline H. regani & 72 & $8 m+16 s m+20 s t+28 a$ & Multiple & Simple & São Francisco River basin & {$[25]$} \\
\hline H. regani & 72 & $10 m+18 s m+44 s t-a$ & - & Multiple & Paranapanema River basin & {$[24]$} \\
\hline H. regani & 72 & $12 m+8 s m+10 s t+42 a$ & Simple & Multiple & Paraná River basin & Present paper \\
\hline H. strigaticeps & 72 & $10 m+16 s m+46 s t-a$ & - & Multiple & Paranapanema River basin & {$[24]$} \\
\hline H. strigaticeps & 72 & $12 m+12 s m+18 s t+30 a$ & Multiple & Multiple & Paraná River basin & Present paper \\
\hline H. albopunctatus & 74 & $8 m+14 s m+16 s t+36 a$ & Simple & Simple & Paraná River basin & Present paper \\
\hline H. paulinus & 74 & $10 m+12 s m+20 s t+32 a$ & Simple & Simple & Paraná River basin & Present paper \\
\hline H. paulinus & 76 & $6 m+16 s m+54 s t-a$ & - & Simple & Paranapanema River basin & {$[24]$} \\
\hline H. nigromaculatus & 76 & $12 m+22 s m+30 s t+12 a$ & Simple & Simple & Paranapanema River basin & {$[22]$} \\
\hline H. iheringii & 80 & $8 m+16 s m+28 s t+28 a$ & Simple & Multiple & Paranapanema River basin & {$[26]$} \\
\hline H. topavae & 80 & $14 m+10 s m+26 s t+30 a$ & Simple & Simple & Paraná River basin & Present paper \\
\hline
\end{tabular}




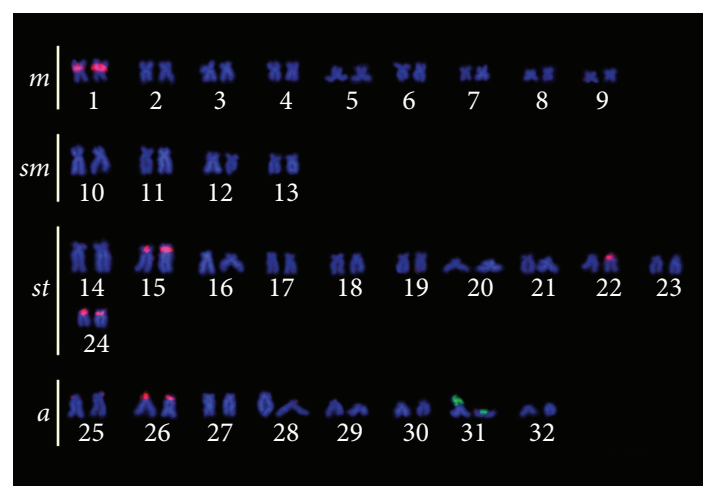

(a)

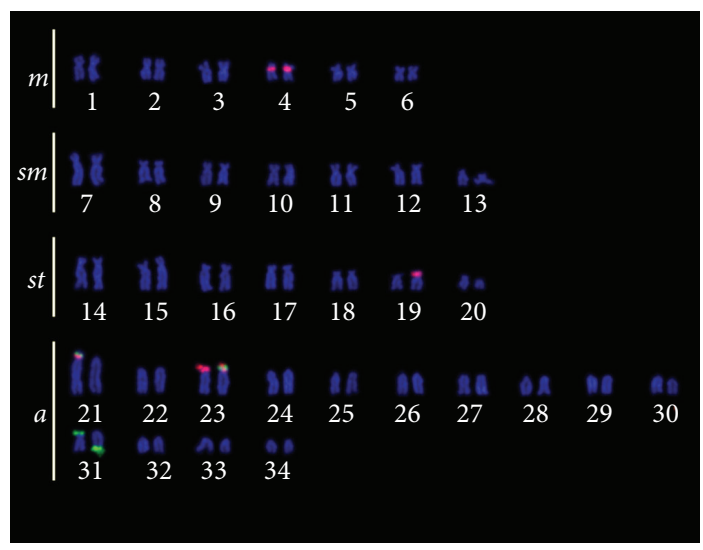

(c)

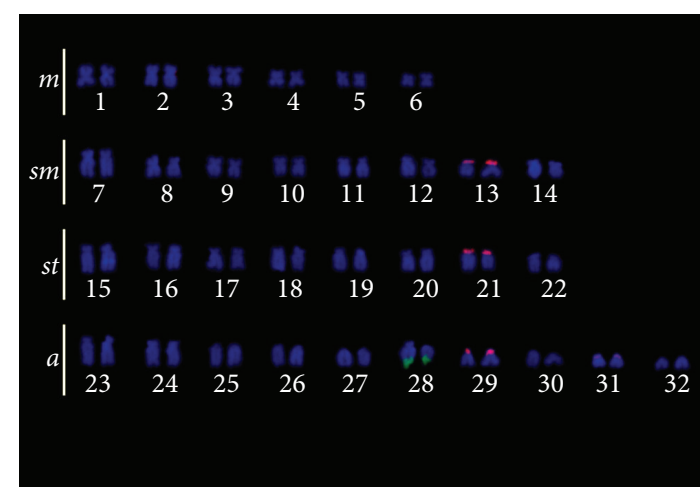

(b)

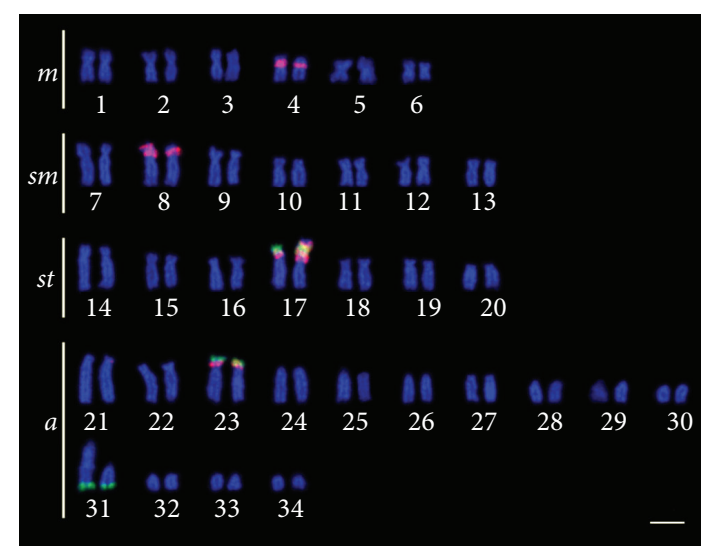

(d)

FIGURE 1: Double FISH karyotypes with 5S rDNA probes (rhodamine, red) and 18S rDNA probes (FITC, green) of (a) Hypostomus faveolus; (b) Hypostomus cochliodon; (c) Hypostomus commersoni from the Piquiri River and (d) Hypostomus commersoni from the Iguaçu River. The bar represents $5 \mu \mathrm{m}$.

this species presented one $18 \mathrm{~S}$ rDNA site, which corroborates the hypothesis that the presence of one $18 \mathrm{~S}$ rDNA site is basal for Hypostomus. As for the $5 \mathrm{~S} \mathrm{rDNA}$, it is not possible to determine whether multiple pairs bearing $5 \mathrm{~S}$ rDNA sites are an ancestral condition for the genus or an apomorphy for the analyzed species.

The species with $2 n=68$ and $2 n=72$ chromosomes ( $H$. ancistroides, $H$. commersoni, $H$. hermanni, $H$. regani, and $H$. strigaticeps) had multiple chromosomes bearing $18 \mathrm{~S}$ rDNA sites. Most species also presented multiple chromosomes bearing 5S rDNA sites, with only $H$. ancistroides and $H$. regani with $5 \mathrm{~S}$ rDNA on a single chromosome pair. There was variation on the location of some sites among the analyzed populations of $H$. commersoni. Only a small number of specimens of $H$. commersoni were collected; therefore it was not possible to verify how the rDNA is distributed within the populations. There is also a description of $H$. regani from Piumhi River (São Francisco River basin, state of São Paulo) with multiple pairs bearing $5 \mathrm{~S}$ rDNA and a single pair bearing $18 \mathrm{~S}$ rDNA [25]. It differs from that observed for the population from the Piquiri River (Paraná River basin, Paraná state) that showed a single pair bearing $5 \mathrm{~S}$ rDNA and multiple pairs bearing $18 \mathrm{~S}$ rDNA. Analyses of other populations of H. ancistroides (Paraná River basin, São Paulo state) [22] and H. strigaticeps (Paraná River basin, between Paraná and São Paulo states) [24] also showed different results from that observed on the present study, with multiple 5S rDNA sites for $H$. ancistroides and two pairs bearing $18 \mathrm{~S}$ rDNA sites for $H$. strigaticeps. Considering the small number of species analyzed through in situ hybridization, there seems to be a relevant occurrence of variation on the number and position of the rDNA sites. Although this group includes species with similar diploid numbers $(2 n=68$ to $2 n=72)$ and number of $5 \mathrm{~S}$ and $18 \mathrm{~S}$ sites, these characteristics are not synapomorphic $[1,7,12]$. The variation on the number of rDNA sites, even among populations of the same species, and the existence of phylogenetic hypotheses that separate species with similar number and location of rDNA sites indicate that this characteristic might not be reliable to establish relationships within Hypostomus, but seems to have potential as a population marker.

The variation on the number and location of $18 \mathrm{~S}$ rDNA sites which occurs even among individuals of the same species suggests the existence of dispersion mechanisms on these sites. The particular chromosome evolution of this genus through centric fissions and pericentric inversions [11, 30] may be partly responsible for this diversity in Hypostomus. However, it is known that some retrotransposons are 


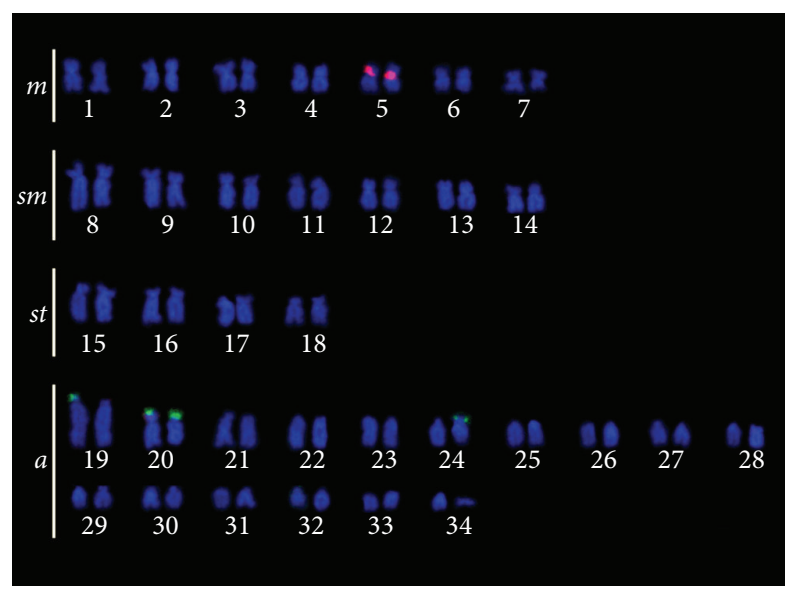

(a)

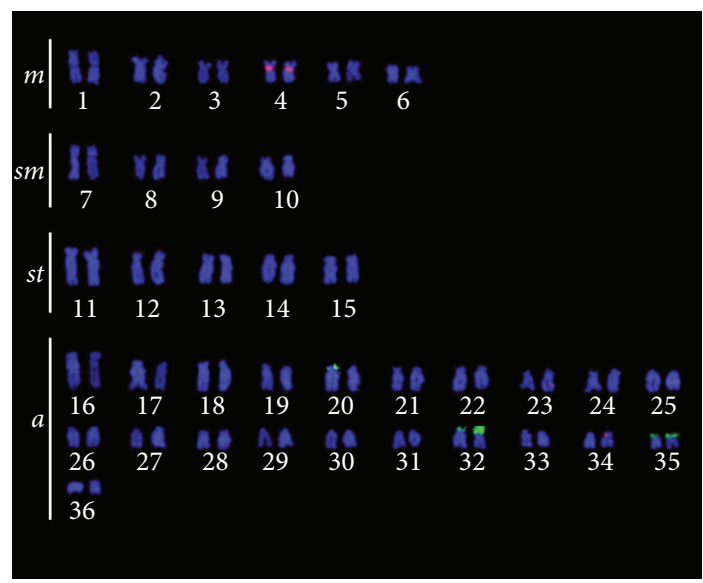

(c)

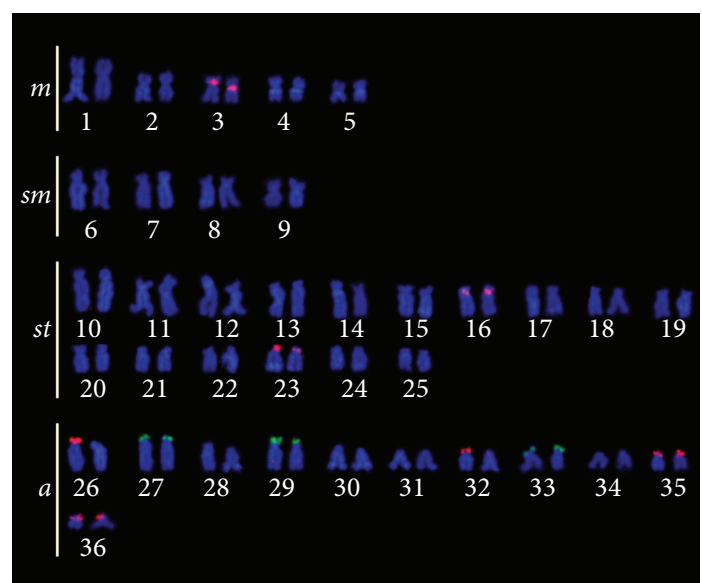

(b)

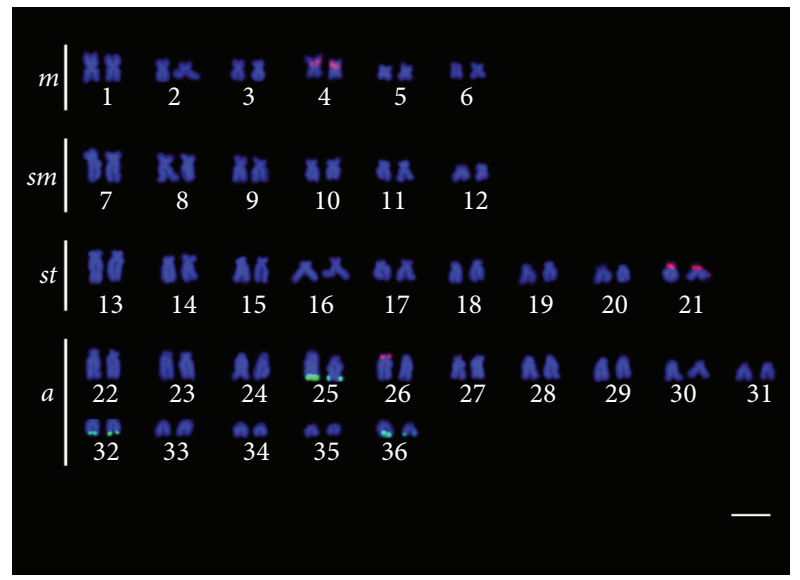

(d)

FIGURE 2: Double FISH karyotypes with 5S rDNA probes (rhodamine, red) and 18S rDNA probes (FITC, green) of (a) Hypostomus ancistroides; (b) Hypostomus hermanni; (c) Hypostomus regani; (d) Hypostomus strigaticeps. The bar represents $5 \mu \mathrm{m}$.

specific for rDNA sequences and that these sites are favorable for the invasion of mobile elements [31-33]. Many types of transposable elements (TEs) are described for teleostean fishes [34]. A possible role of TEs as a source of rRNA genes movement, which could generate the spreading of ribosomal clusters/copies, was visualized in fishes [35-37]. Hence, the organization of rRNA gene clusters seems to reflect their intense and particular evolutionary pathway and not the evolutionary history of the associated taxa in some fish group [36, 38]. Similar mechanisms might be responsible for the variation on the number and position of 18S rDNA sites observed in Hypostomus. The presence of adjacent heterochromatin on these sites may also facilitate genetic exchanges among non-homologous chromosomes, causing the dispersion of these sequences on the genome.

The species with $2 n=74$ and $2 n=80$ chromosomes ( $H$. albopunctatus, $H$. aff. paulinus, and $H$. topavae) showed single chromosome pairs bearing $5 \mathrm{~S}$ and $18 \mathrm{~S}$ rDNA sites. However, H. iheringii (Regan, 1908) analyzed by Traldi et al. [26] showed a single pair bearing $5 \mathrm{~S}$ rDNA and multiple pairs bearing $18 \mathrm{~S}$ rDNA. Also, some species within this diploid number group have been reported with multiple NORs, such as $H$. aff. agna $(2 n=74)$ [39], H. nigromaculatus (Schubart, 1964) $(2 n=76)$ [40], and Hypostomus sp. E $(2 n=80)$ [40], therefore multiple $18 \mathrm{~S}$ rDNA sites. In fact, $H$. nigromaculatus from the Lapa stream, São Paulo state, was reported to have $5 \mathrm{~S}$ and $18 \mathrm{~S}$ rDNA each on only one chromosome pair [22], while populations from Mogi-Guaçu and Tibagi Rivers showed multiple AgNORs, pointing to the existence of multiple 18 rDNA sites on such populations [40]. These results indicate that it is probable that this group of species also shows variations on the number and locations of rDNA sites among them. If it really is so, the whole group of species with $2 n=$ 68 to $2 n=84$ would be very heterogeneous regarding the number and location of the $18 \mathrm{~S}$ rDNA sites, indicating that this character changed recurrently during the chromosomal diversification of the genus. All species in this diploid number range $(2 n=74$ to $2 n=84)$ analyzed until the present moment present a single pair bearing $5 \mathrm{~S}$ rDNA sites. Further analyses are necessary to determine whether the increase of the diploid number is associated with the loss of 5S rDNA sites.

The presence of a centromeric/pericentromeric $5 \mathrm{~S}$ rDNA site on the short arm of a metacentric/submetacentric pair is a particular feature of the $5 \mathrm{~S}$ rDNA observed on most 


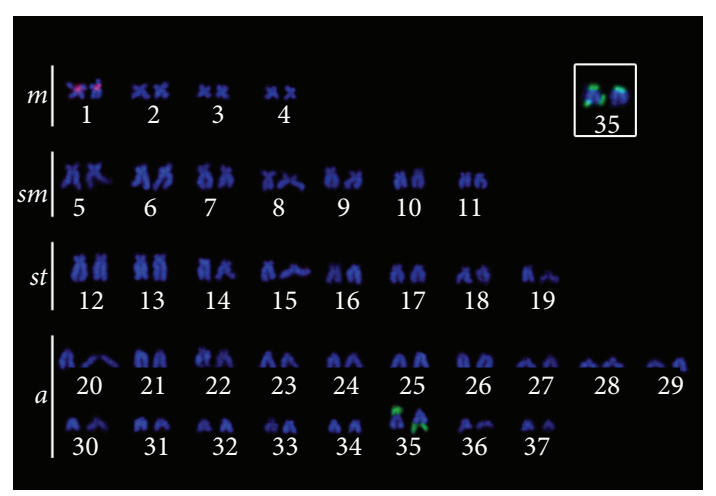

(a)

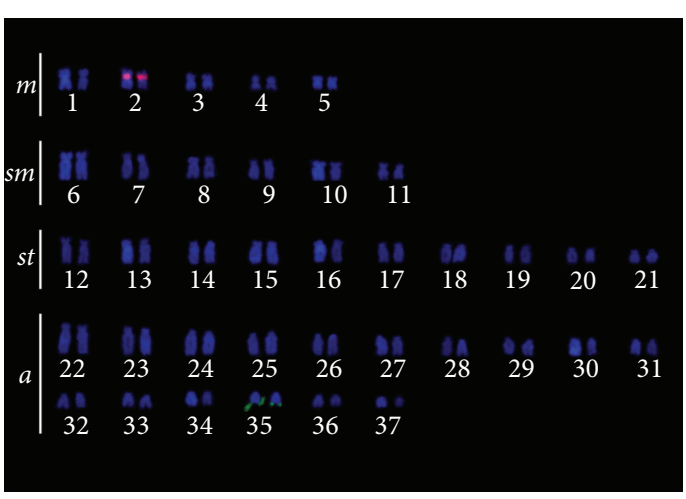

(b)

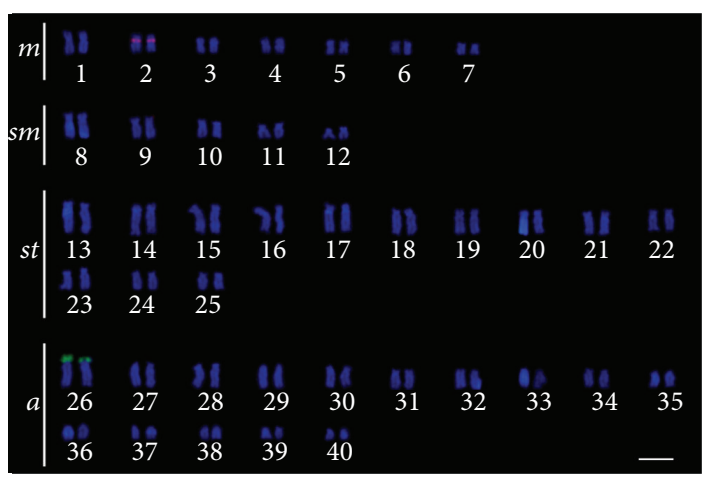

(c)

FIGURE 3: Double FISH karyotypes with 5S rDNA probes (rhodamine, red) and $18 \mathrm{~S}$ rDNA probes (FITC, green) of (a) Hypostomus albopunctatus, with a variation of the position of the $18 \mathrm{~S}$ rDNA sites evidenced on the box; (b) Hypostomus aff. paulinus and (c) Hypostomus topavae. The bar represents $5 \mu \mathrm{m}$.

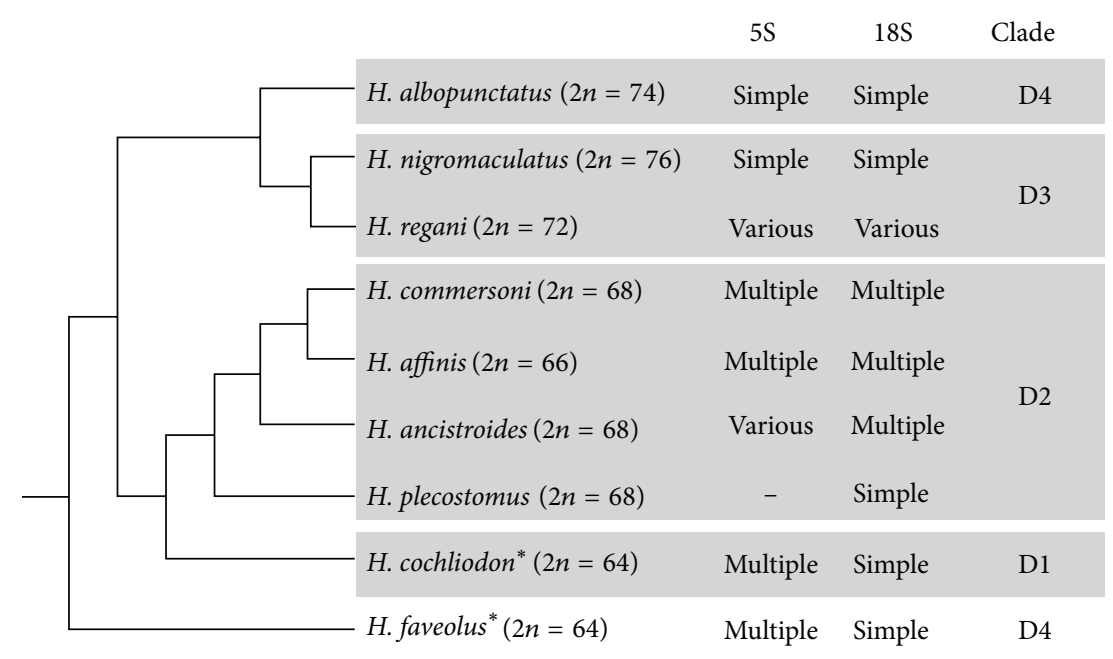

FIGURE 4: Data on rDNA sites number plotted against the phylogenetic relationship between species. The cladogram is only representative and is based on the phylogeny proposed by Montoya-Burgos (2003), with addition of species marked with an asterisk. "Clades" refer to the clades proposed by the same author. Hypostomus cochliodon is added considering information from Armbruster [1] and H. faveolus considering information from Martinez [12]. 
Hypostomus species analyzed on the present paper and also on other previously analyzed populations/species [20-22, 24, 25]. All species of Hypostomus analyzed so far but $H$. cochliodon have this $5 \mathrm{~S}$ rDNA site on this particular location. Traldi et al. [22] consider the frequent occurrence of this site in this particular location a possible primitive condition for the genus. Possibly, the location of this site favored its permanence on the karyotype of most species, while telomeric sites seem to vary more easily. Further analyses are necessary to identify whether the lack of this particular $5 \mathrm{~S}$ rDNA site occurs in other species of the $H$. cochliodon group or only in $H$. cochliodon or even on the studied population of this species.

Syntenic 5S and $18 \mathrm{~S}$ rDNAs were observed in $H$. commersoni. The occurrence of syntenic $5 \mathrm{~S}$ and $18 \mathrm{~S}$ rDNAs is considered primitive for Loricariidae, with Trichomycteridae as outgroup [27]. This characteristic was already described for species of the subfamilies Neoplecostominae and Hypoptopomatinae [27] and in Hypostominae, for the tribes Ancistrini [29] and Hypostomini [22]. For Hypostomini, two species presented syntenic $5 \mathrm{~S}$ and $18 \mathrm{~S}$ rDNAs: $H$. ancistroides and H. tapijara Oyakawa, Akama, and Zanata, 2005 [22]. On the present study we presented one more species of Hypostomini ( $H$. commersoni) that presented syntenic $5 \mathrm{~S}$ and $18 \mathrm{~S}$ rDNAs. All Hypostominae tribes that were analyzed through in situ hybridization with $5 \mathrm{~S}$ and $18 \mathrm{~S}$ rDNA probes until now present species with syntenic rDNAs. Although this condition may also be the primitive condition for Hypostominae, given its occurrence on different tribes, further studies are necessary to determine if it was maintained in Hypostomus. If $H$. faveolus really is a basal species for the genus, the possibility that the syntenic condition of the rDNA classes was lost early in the genus and then it reappeared due the apparent mobility of the rDNA on the genome must be considered as well.

The analysis here presented still includes a rather small number of species, considering the whole genus. However, we could observe a great variability on the number and location of the rDNA sites, reinforcing the hypothesis proposed by Artoni and Bertollo [41] that Hypostomus has a divergent chromosomal evolution when compared to other Hypostominae that tend to maintain more ancestral characteristics, such lower diploid numbers and one chromosome pair bearing AgNORs, therefore 18S rDNA. Further studies including more species, especially from northern basins, and analyses on the rDNAs and adjacent sequences would greatly contribute to clarify the dispersion mechanisms of these sequences within the genome of Hypostomus.

\section{Conflict of Interests}

The authors declare that there is no conflict of interests regarding the publication of this paper.

\section{Acknowledgments}

The authors are grateful to Instituto Chico Mendes de Conservação da Biodiversidade (ICMBio) for authorizing the capture of fishes (License: SISBIO 10522-1). The authors thank Unioeste and the Núcleo de Pesquisas em Limnologia, Ictiologia e Aqüicultura (Nupélia), for logistical support. This study was financed by Fundação Araucária (Fundação Araucária de Apoio ao Desenvolvimento Científico e Tecnológico do Estado do Paraná), CAPES (Coordenadoria de Aperfeiçoamento de Ensino Superior), and CNPq (Conselho Nacional de Desenvolvimento Científico e Tecnológico).

\section{References}

[1] J. W. Armbruster, "Phylogenetic relationships of the suckermouth armoured catfishes (Loricariidae) with emphasis on the Hypostominae and the Ancistrinae," Zoological Journal of the Linnean Society, vol. 141, no. 1, pp. 1-80, 2004.

[2] C. J. Ferraris Jr., "Checklist of catfishes, recent and fossil (Osteichthyes: Siluriformes), and catalogue of siluriform primary types," Zootaxa, vol. 1418, pp. 1-628, 2007.

[3] C. Weber, "Hypostominae," in Check List of the Freshwater Fishes of South and Central America, R. E. Reis, S. O. Kullander, and C. J. Ferraris Jr., Eds., pp. 351-372, Edipucrs, Porto Alegre, Brazil, 2003.

[4] R. E. Reis, E. H. L. Pereira, and J. W. Armbruster, "Delturinae, a new loricariid catfish subfamily (Teleostei, Siluriformes), with revisions of Delturus and Hemipsilichthys," Zoological Journal of the Linnean Society, vol. 147, no. 2, pp. 277-299, 2006.

[5] M. C. Chiachio, C. Oliveira, and J. I. Montoya-Burgos, "Molecular systematic and historical biogeography of the armored Neotropical catfishes Hypoptopomatinae and Neoplecostominae (Siluriformes: Loricariidae)," Molecular Phylogenetics and Evolution, vol. 49, no. 2, pp. 606-617, 2008.

[6] J. I. Montoya-Burgos, S. Muller, C. Weber, and J. Pawlowski, "Phylogenetic relationships of the Loricariidae (Siluriformes) based on mitochondrial rRNA gene sequences," in Phylogeny and Classification of Neotropical Fishes, L. R. Malabarba, R. E. Reis, R. P. Vari, Z. M. S. Lucena, and C. A. S. Lucena, Eds., pp. 363-374, Edipucrs, Porto Alegre, Brazil, 1998.

[7] J. I. Montoya-Burgos, "Historical biogeography of the catfish genus Hypostomus (Siluriformes: Loricariidae), with implications on the diversification of Neotropical ichthyofauna," Molecular Ecology, vol. 12, no. 7, pp. 1855-1867, 2003.

[8] J. Muramoto, S. Ohno, and N. B. Atkin, "On the diploid state of the fish order Ostariophysi," Chromosoma, vol. 24, no. 1, pp. 59-66, 1968.

[9] V. Bueno, P. C. Venere, C. H. Zawadzki, and V. P. Margarido, "Karyotypic diversification in Hypostomus Lacépède, 1803 (Siluriformes, Loricariidae): biogeographical and phylogenetic perspectives," Reviews in Fish Biology and Fisheries, vol. 23, no. 1, pp. 103-112, 2013.

[10] S. S. Cereali, E. Pomini, R. Rosa, C. H. Zawadzki, O. Froehlich, and L. Giuliano-Caetano, "Karyotype description of two species of Hypostomus (Siluriformes, Loricariidae) of the Planalto da Bodoquena, Brazil," Genetics and Molecular Research, vol. 7, no. 3, pp. 583-591, 2008.

[11] V. Bueno, C. H. Zawadzki, and V. P. Margarido, "Trends in chromosome evolution in the genus Hypostomus Lacépède, 1803 (Osteichthyes, Loricariidae): a new perspective about the correlation between diploid number and chromosomes types," Reviews in Fish Biology and Fisheries, vol. 22, no. 1, pp. 241-250, 2012. 
[12] E. R. M. Martinez, Estudo da evolução do gênero Hypostomus (Teleostei, Siluriformes, Loricariidae) com base em caracteres cromossômicos e seqüências de DNA [Ph.D. thesis], Universidade Estadual Paulista, São Paulo, Brazil, 2009.

[13] S. P. Griffiths, "The use of clove oil as an anaesthetic and method for sampling intertidal rockpool fishes," The Journal of Fish Biology, vol. 57, no. 6, pp. 1453-1464, 2000.

[14] L. A. C. Bertollo, C. S. Takahashi, and O. Moreira Filho, "Cytotaxonomic considerations on Hoplias lacerdae (Pisces, Erythrinidae)," Brazilian Journal of Genetics, vol. 1, no. 2, pp. 103-120, 1978.

[15] D. Pinkel, T. Straume, and J. W. Gray, "Cytogenetic analysis using quantitative, high-sensitivity, fluorescence hybridization," Proceedings of the National Academy of Sciences of the United States of America, vol. 83, no. 9, pp. 2934-2938, 1986.

[16] V. P. Margarido and O. Moreira-Filho, "Karyotypic differentiation through chromosome fusion and number reduction in Imparfinis hollandi (Ostariophysi, Heptapteridae)," Genetics and Molecular Biology, vol. 31, no. 1, pp. 235-238, 2008.

[17] T. Hatanaka and P. M. Galetti, "Mapping of the $18 \mathrm{~S}$ and $5 \mathrm{~S}$ ribosomal RNA genes in the fish Prochilodus argenteus Agassiz, 1829 (Characiformes, Prochilodontidae)," Genetica, vol. 122, no. 3, pp. 239-244, 2004.

[18] C. Martins and P. M. Galetti Jr., "Chromosomal localization of 5S rDNA genes in Leporinus fish (Anostomidae, Characiformes)," Chromosome Research, vol. 7, no. 5, pp. 363-367, 1999.

[19] A. Levan, K. Fredga, and A. A. Sandberg, "Nomenclature for centromeric position on chromosomes," Hereditas, vol. 52, no. 2, pp. 201-220, 1964.

[20] K. F. Kavalco, R. Pazza, L. A. C. Bertollo, and O. Moreira-Filho, "Gene mapping of 5s rDNA sites in eight fish species from the Parába do Sul river basin, Brazil," Cytogenetic and Genome Research, vol. 106, no. 1, pp. 107-110, 2004.

[21] K. F. Kavalco, R. Pazza, L. A. C. Bertollo, and O. Moreira-Filho, "Karyotypic diversity and evolution of Loricariidae (Pisces, Siluriformes)," Heredity, vol. 94, no. 2, pp. 180-186, 2005.

[22] J. B. Traldi, D. R. Blanco, M. R. Vicari et al., "Chromosomal diversity in Hypostomus (Siluriformes, Loricariidae) with emphasis on physical mapping of $18 \mathrm{~S}$ and 5S rDNA sites," Genetics and Molecular Research, vol. 12, no. 1, pp. 463-471, 2013.

[23] A. L. Alves, R. S. de Borba, A. P. B. Pozzobon et al., "Localization of $18 \mathrm{~S}$ ribosomal genes in suckermouth armoured catfishes Loricariidae (Teleostei, Siluriformes) with discussion on the Ag-NOR evolution," Comparative Cytogenetics, vol. 6, no. 3, pp. 315-321, 2012.

[24] M. Rubert, R. Da Rosa, F. C. Jerep, L. A. C. Bertollo, and L. Giuliano-Caetano, "Cytogenetic characterization of four species of the genus Hypostomus Lacépède, 1803 (Siluriformes, Loricariidae) with comments on its chromosomal diversity," Comparative Cytogenetics, vol. 5, no. 5, pp. 397-410, 2011.

[25] E. de Oliveira Mendes-Neto, M. R. Vicari, R. F. Artoni, and O. Moreira-Filho, "Description of karyotype in Hypostomus regani (Ihering, 1905) (Teleostei, Loricariidae) from the Piumhi river in Brazil with comments on karyotype variation found in Hypostomus," Comparative Cytogenetics, vol. 5, no. 2, pp. 133142, 2011.

[26] J. B. Traldi, M. R. Vicari, D. R. Blanco, J. D. F. Martinez, R. F. Artoni, and O. Moreira-Filho, "First karyotype description of Hypostomus iheringii (Regan, 1908): a case of heterochromatic polymorphism," Comparative Cytogenetics, vol. 6, no. 2, pp. 115$125,2012$.
[27] K. Ziemniczak, A. V. Barros, K. O. Rosa et al., "Comparative cytogenetics of Loricariidae (Actinopterygii: Siluriformes): emphasis in Neoplecostominae and Hypoptopomatinae," Italian Journal of Zoology, vol. 79, no. 4, pp. 492-501, 2012.

[28] R. F. Artoni and L. A. C. Bertollo, "Cytogenetic studies on Hypostominae (Pisces, Siluriformes, Loricariidae). Considerations on karyotype evolution in the genus Hypostomus," Caryologia, vol. 49, no. 1, pp. 81-90, 1996.

[29] S. Mariotto, L. Centofante, M. R. Vicari, R. F. Artoni, and O. Moreira-Filho, "Chromosomal diversification in ribosomal DNA sites in Ancistrus Kner, 1854 (Loricariidae, Ancistrini) from three hydrographic basins of Mato Grosso, Brazil," Comparative Cytogenetics, vol. 5, no. 4, pp. 31-42, 2011.

[30] R. F. Artoni and L. A. C. Bertollo, "Trends in the karyotype evolution of Loricariidae fish (Siluriformes)," Hereditas, vol. 134, no. 3, pp. 201-210, 2001.

[31] Y. Xiong, W. D. Burke, J. L. Jakubczak, and T. H. Eickbush, "Ribosomal DNA insertion elements R1Bm and R2Bm can transpose in a sequence specific manner to locations outside the 28 S genes," Nucleic Acids Research, vol. 16, no. 22, pp. 1056110573, 1988.

[32] K. K. Kojima and H. Fujiwara, "Evolution of target specificity in R1 clade non-LTR retrotransposons," Molecular Biology and Evolution, vol. 20, no. 3, pp. 351-361, 2003.

[33] K. K. Kojima and H. Fujiwara, "Cross-genome screening of novel sequence-specific non-LTR retrotransposons: various multicopy RNA genes and microsatellites are selected as targets," Molecular Biology and Evolution, vol. 21, no. 2, pp. 207-217, 2004.

[34] J. N. Volff, "Genome evolution and biodiversity in teleost fish," Heredity, vol. 94, no. 3, pp. 280-294, 2005.

[35] M. da Silva, D. A. Matoso, M. R. Vicari, M. C. de Almeida, V. P. Margarido, and R. F. Artoni, "Physical mapping of 5S rDNA in two species of knifefishes: Gymnotus pantanal and Gymnotus paraguensis (Gymnotiformes)," Cytogenetic and Genome Research, vol. 134, no. 4, pp. 303-307, 2011.

[36] S. S. R. Milhomem, P. C. Scacchetti, J. C. Pieczarka et al., "Are NORs always located on homeologous chromosomes? A fish investigation with rDNA and whole chromosome probes in Gymnotus fishes (gymnotiformes)," PLoS ONE, vol. 8, no. 2, Article ID e55608, 2013.

[37] D. Piscor, D. B. Ribacinko-Piscor, C. A. Fernandes, and P. P. Parise-Maltempi, "Cytogenetic analysis in three Bryconamericus species (Characiformes, Characidae): first description of the $5 \mathrm{~S}$ rDNA-bearing chromosome pairs in the genus," Molecular Cytogenetics, vol. 6, no. 1, article 13, 2013.

[38] R. T. Nakajima, D. C. Cabral-de-Mello, G. T. Valente, P. C. Venere, and C. Martins, "Evolutionary dynamics of rRNA gene clusters in cichlid fish," BMC Evolutionary Biology, vol. 12, no. 1, article 198, 2012.

[39] E. R. M. Martinez, C. H. Zawadzki, F. Foresti, and C. Oliveira, "Cytogenetic analysis of five Hypostomus species (Siluriformes, Loricariidae)," Genetics and Molecular Biology, vol. 34, no. 4, pp. 562-568, 2011.

[40] M. Rubert, C. H. Zawadzki, and L. Giuliano-Caetano, "Cytogenetic characterization of Hypostomus nigromaculatus (Siluriformes: Loricariidae)," Neotropical Ichthyology, vol. 6, no. 1, pp. 93-100, 2008.

[41] R. F. Artoni and L. A. C. Bertollo, "Nature and distribution of constitutive heterochromatin in fishes, genus Hypostomus (Loricariidae)," Genetica, vol. 106, no. 3, pp. 209-214, 1999. 

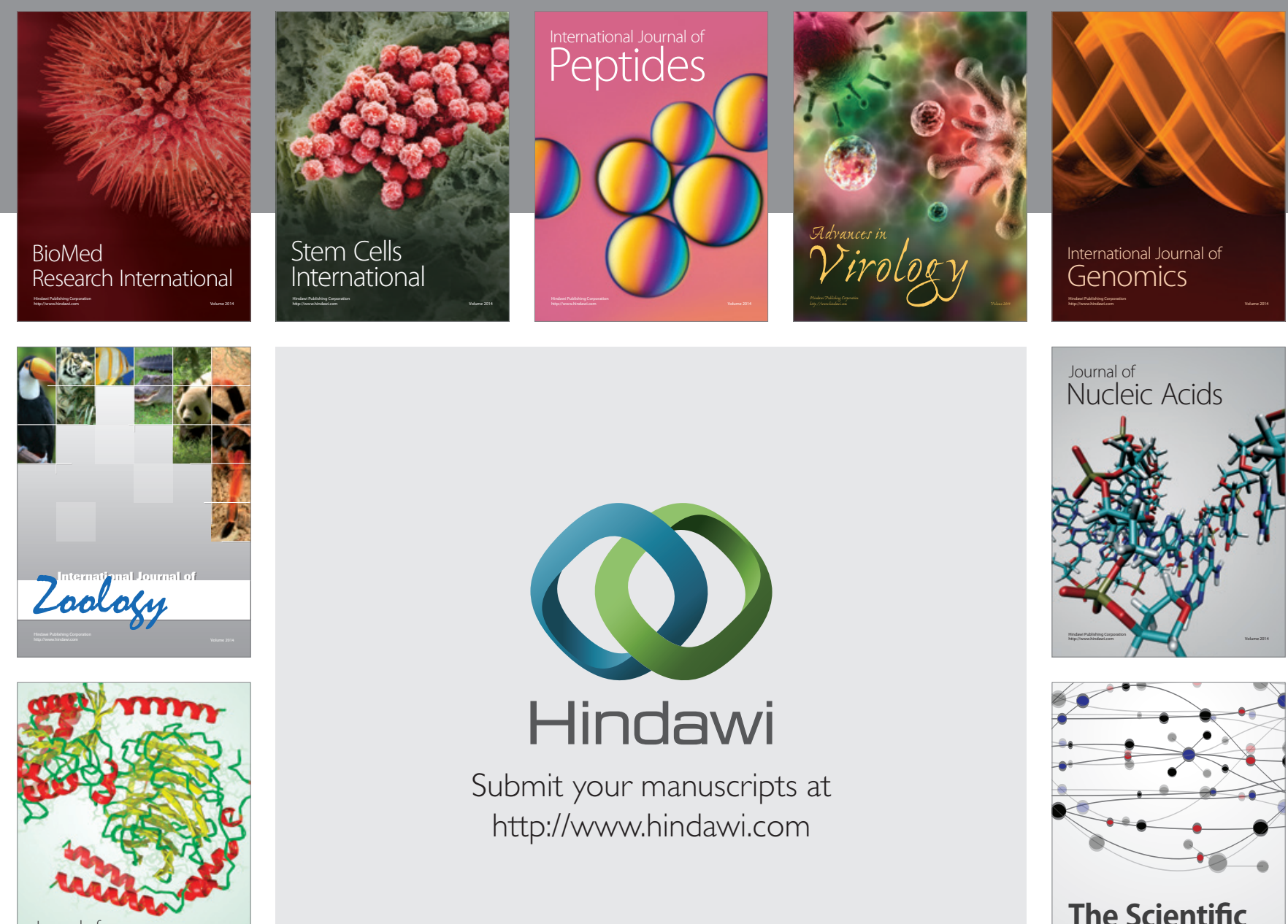

Submit your manuscripts at

http://www.hindawi.com

Journal of
Signal Transduction
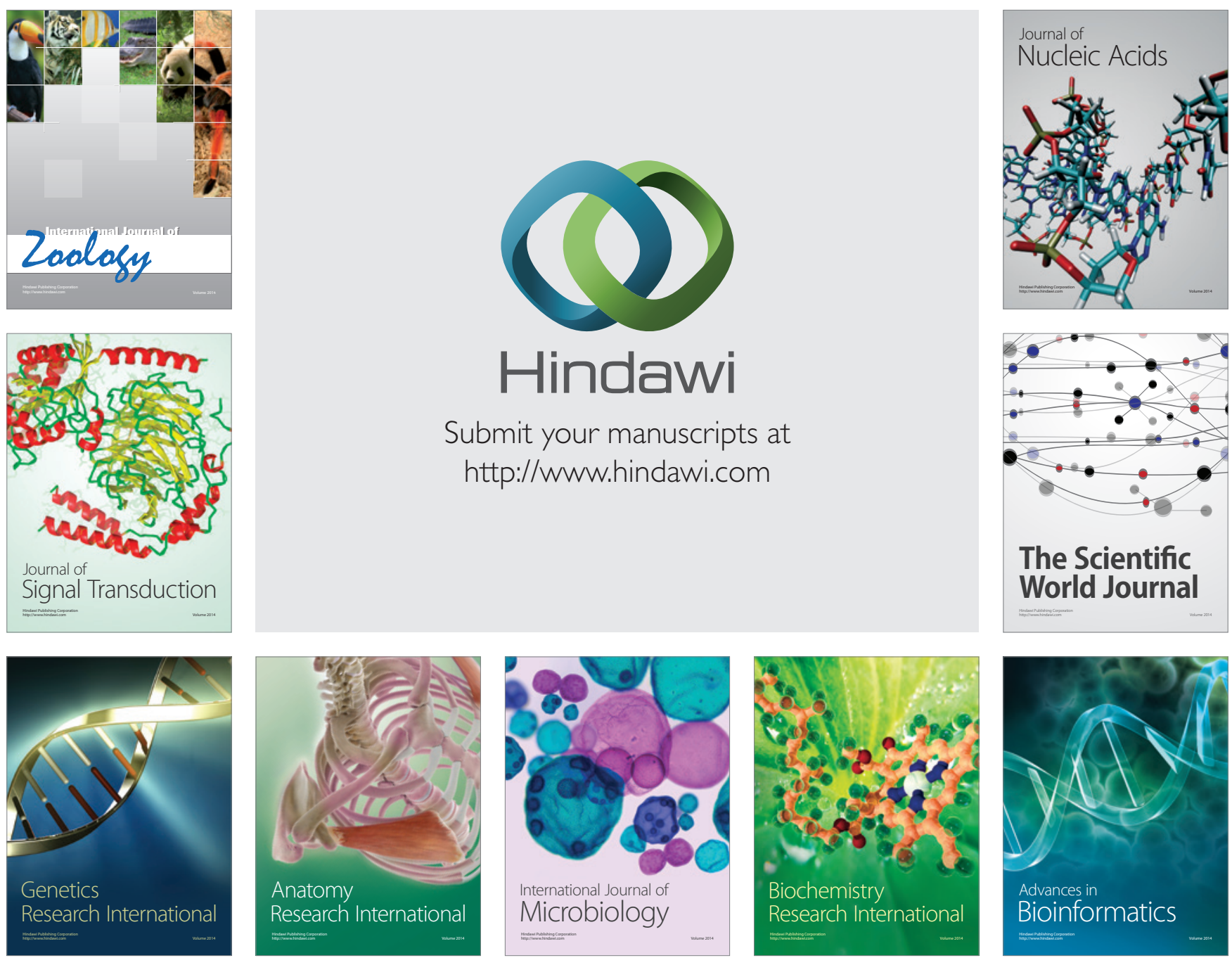

The Scientific World Journal
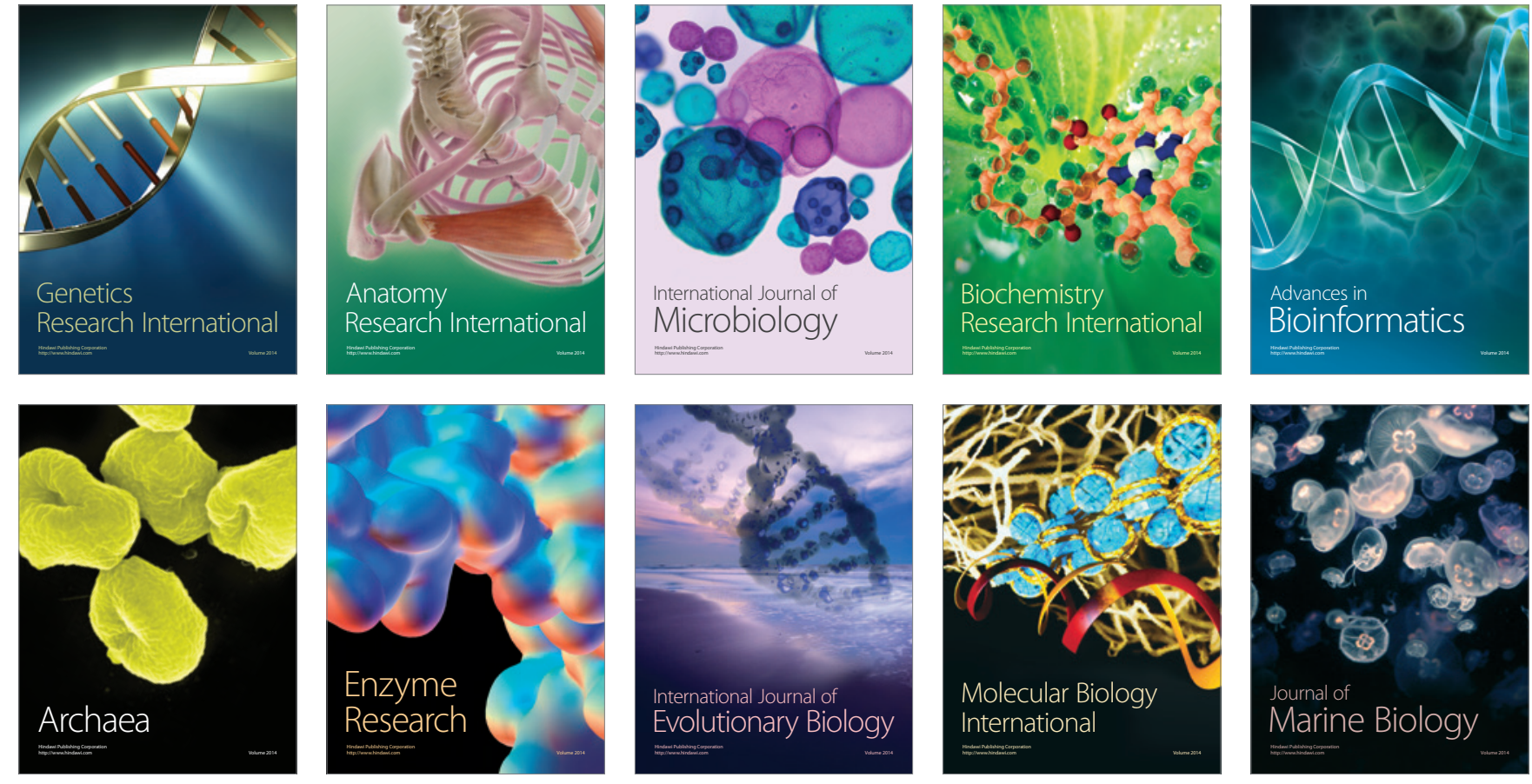